\title{
PENERAPAN METHODOLOGY SIX SIGMA UNTUK MENGURANGI PEMBOROSAN BIAYA OPERASIONAL WASTE WATER TREATMENT DI PT CLARIANT INDONESIA (STUDI KASUS DI PERUSAHAAN KIMIA)
}

\author{
${ }^{1}$ Nur Fadilah Fatma, ${ }^{2}$ Segi Anggi Pradipta \\ ${ }^{1,2 .}$ Program Studi Teknik Industri, Fakultas Teknik \\ Universitas Muhammadiyah Tangerang \\ Jl. Perintis Kemerdekaan I/33, Cikokol, Kota Tangerang
}

\begin{abstract}
A b strak
One of the method used to improve of process to give the solution to increase process standart in internal manufacturing purpose to minimize defect or non conforming and reduce waste so the trend of failure product reduced in period is six sigma method. Through of application cycles of DMAIC (Define, Measure, Analyze, Improve and Control) in six sigm, so one of problem can to clear define the root causes and can to improve with structural. This riset in PT Clariant Indonesia Tangerang Site, in Waste Water Treatment analysis costing needed to operasional water treatment in one year. Where there are several cost aloction not yet effective and efficient so occur waste of operational costing Waste Water Treatment in 2015. Result of the riset is success to defined several root causes and defined several solution to tackle problem waste of cost operational in Waste Water Treatment. In the end of riset success to reduce operational cost Waste Water Treatment till 360 mio IDR in 6 months Control phase.
\end{abstract}

Keyword : Quality Control, Six Sigma, DMAIC, Waste Water Treatment, Continuous Improvement.

\section{PENDAHULUAN}

Dalam proses pengolahan air limbah di Waste Water Treatment tentunya di butuhkan biaya untuk operasional seperti biaya listrik, tenaga kerja, pembelian kimia untuk proses, perbaikan mesin dan infrastuktur (maintenance), dan biaya penunjang operasional yang lain. Ditahun 2015 total biaya operasional Waste Water Treatment mencapai 5,3 milyar setahun meningkat significant dari biaya operasional di tahun 2014 sebesar 4,1 milyar. Hal ini dianggap oleh Management PT. Clariant Indonesia terjadi masalah yang harus di selesaikan dengan terstruktur supaya hal seperti ini tidak terjadi di kemudian hari.

Beberapa dampak meningkatnya biaya operasional pada tahun 2015 sebesar 1,2 milyar di banding tahun 2014 yang terjadi akan berpengaruh ke harga jual produk / CP1, karena biaya operasional Waste Water Treatment merupakan salah satu komponen yang akan di konversi untuk menentukan harga jual produk. Maka semakin besar biaya operasional Waste Water Treatment akan semakin besar harga jual produk per $\mathrm{kg}$.

Six sigma adalah konsep statistik yang mengukur suatu proses yang berkaitan dengan cacat atau kerusakan. Mencapai enam sigma berarti bahwa proses yang berjalan hanya menghasilkan 3,4 cacat per sejuta peluang, dengan kata lain proses itu berjalan hampir sempurna. Sigma (huruf abjad Yunani ke-18) adalah istilah dalam statisik untuk menunjukkan penyimpangan standar (standard deviation) (Greg Brue, 2002 : 2). six sigma adalah implementasi yang tepat, fokus, dan efektif dalam membuktikan prinsip dan teknik mengenai kualitas.

Konsep dalam penerapan six sigma adalah suatu upaya terus-menerus untuk menghilangkan waste dan meningkatkan nilai tambah (value 4 added) produk (barang dan/atau jasa) agar memberikan nilai kepada pelanggan (customer value). Tujuannya adalah meningkatkan customer value melalui peningkatan terus-menerus rasio antara nilai tambah terhadap pemborosan 
(the value-to-waste ratio) dengan berfokus pada identifikasi dan eliminasi aktivitas- aktivitas tidak bernilai tambah (non-valueadding activities) dalam desain, produksi (untuk bidang manufaktur) atau operasi (untuk bidang jasa), dan supply chain management yang berkaitan langsung dengan pelanggan (Gaspersz \& Avanti, 2011). Aktivitas yang menghabiskan sumber daya lebih dari yang dibutuhkan tergolong sebagai waste dan memiliki kesempatan untuk diperbaiki. Jenis-jenis aktivitas yang terdapat dalam proses diuraikan berikut ini (Sarkar, 2008) :

1. Value-added activities Value-added activities

2. Business-value-added activities

3. Business-value-added activities

4. Non-value-added activities.

\section{METODE PENELITIAN}

Analisa data di lakukan dengan menggunakan beberapa alat bantu six sigma antara lain sebagai berikut :

1. Diagram Pareto di gunakan untuk

mengidentifikasi biaya terbesar sampai yang terkecil sehingga di dapatkan $80 \%$ biaya tersebar operasional untuk lebih fokus dalam melakukan tidakan perbaikan.

2. Project charter di gunakan untuk menjelaskan secara singkat apa yang menjadi latar belakang masalah, massalah sebenarnya seperti apa dan tujuan yang ingin di capai.

3. SIPOC digunakan untuk mengetahui proses di mulai dan proses akhir dari suatu proses yang akan di lakukan penelitian.

4. Fishbone digunakan untuk mencari akar penyebab masalah yang terjadi.

5. Tool 3 di gunakan untuk menganalisa akar penyebab masalah apakah valid atau tidak sebelum di putuskan solusinya.

6. Operational Definition digunakan untuk menjelaskan tentang apa yang menjadi output measurenment sehingga jelas dan disepakati bersama. Bertujuan supaya tidak ada perbedaan persepsi tentang data dan pengukurannya.

\section{HASIL DAN PEMBAHASAN}

Setelah seluruh data yang diperlukan terkumpul, data tersebut akan diolah melalui 5 fase dalam Six Sigma yang disebut Six Sigma Improvement Framework atau Six Sigma Breakthrough Strategy. Untuk menganalisa pemborosan yang terjadi di departemen Waste Water Treatment PT. Clariant Indonesia menggunakan methodologi six sigma harus membagi fase penelitian tersebut sesuai dengan methodologi six sigma DMAIC (Define, Measure, Analyze, Improve, Control). Sebelum di mulai penelitian dilakukan Gemba aktivitas untuk mengidentifikasi awal sebagai dugaan sementara apa saja yang berpotensi terjadi masalah yang mengakibatkan pemborosan biaya operasional Waste Water Treatment. Gemba analisis dilakukan dengan melakukan wawancara ke operator proses, melihat alur proses dan membuka laporan SAP di tahun 2016. Dari hasil Gemba di diskusikan ke proses owner sebagai PIC yang memiliki pain dari proses tersebut. Process owner juga memberikan masukan apa saja yang berpotensi terjadi masalah selama tahun 2016 sehingga mendapatkan dugaan awal sebagai berikut:

- Electricity consumption tinggi

- Solid Content press cake rendah

- Chemicals consumption tinggi untuk proses \& adjustment

- Maintenance cost tinggi

Dari hasil dugaan diatas dapat di gunakan sebagai acuan awal supaya lebih dapat memfokuskan dan memprioritaskan penelitian. Tetapi karena ini hanya dugaan awal harus di verifikasi dengan penerapan six sigma supaya proses perbaikan dilakukan secara terstruktur 
dengan tahapan DMAIC (Define, Measure, Analyze, Improve, Control). Berikut adalah hasil analisa dan pembahasan menggunakan metodologi six sigma dan alat bantu statistiknya.

Define (Perumusan)

Fase Define bertujuan untuk menjelaskan apa masalah yang terjadi dalam project six sigma. Dilakukan pendefisian latar belakang dari masalah yang terjadi, apa masalahnya, apa tujuannya, berapa lama timeline nya dan menetapkan team member yang akan membantu dalam menyelesaikan project yang tercakup didalam project charter. Team member berasal dari proses yang terkait karena diharapkan mempu memberi masukan dan ide - ide dari existing proses yang sedang di lakukan. Alat bantu six sigma yang digunakan di dalam fase define adalah project charter, diagram SIPOC, dan TOOL 1 customer needs.

a. Business case./Latar belakang : Cost adalah yang yang sangat penting untuk operasional perusahaan termasuk bagian Waste Water Treatment. Pengolahan air limbah membutuhkan cost untuk pembelian kimia, pembuangan sludge, perbaikan mesin, biaya karyawan, pembelian spare part dan pembayaran listrik. Tetapi penggunaan harus di lakukan secara efektif dan efisien karena akan berdampak pada harga produk yang di hasilkan karena cost Waste Water Treatment menjadi salah satu bagian yang di konversikan ke harga jual produk. Tahun 2015 bahwa cost operational departemen Waste Water Treatment menghabiskan 5,3 milyar per tahun, meningkat significant di banding 2014 sebanyak 4,1 milyar. Tidak ada perubahan kapasitas produksi ditahun 2014 dan 2015. Pada tahun 2014 menghasilkan total produksi sebesar 41,197 ton dengan debit air limbah 65,753 m3 dan total load sebesar 39.4 ton/m3. Sedangkan di tahun 2015 total produksi sebesar 33,244 ton dengan debit air limbah $64,161 \mathrm{~m} 3$ dan total load sebesar 41.6 ton/m3. Tetapi secara cost operasional Waste Water Treatment lebih besar ditahun 2015. perlu untuk

b. TOOL I (one) Customer Needs Alat bantu selanjutnya di dalan fase Define adalah Tool I, biasa di sebut dengan customer need. Hal ini penting karena akan dapat di ketahui apa keinginan customer yang akan di penuhi untuk pencapaian kepuasan nya. Tetapi berdasarkan penelitian yang dilakukan Waste Water Treatment tidak berhubungan secara langsnung dengan customer bisnis maleinkan customer yang di maksut adalah Management terkait atau process owner yang memiliki pain karena berhubungan dengan bisnis. CTB (critical to business) di rumuskan dari suara stakeholder atau biasa di sebut dengan VOB (voice of business) perumusan tersebut dapat di lihat dari gambar di bawah ini

Tabel 1 VOB \& CTB

\begin{tabular}{|l|l|l|}
\hline \multicolumn{1}{|c|}{$\begin{array}{c}\text { VOB } \\
\text { (Voice of the business) }\end{array}$} & \multicolumn{1}{|c|}{$\begin{array}{c}\text { Key Issue } \\
\text { ("True } \\
\text { Need") }\end{array}$} & $\begin{array}{c}\text { CTB's (Critical to } \\
\text { business) }\end{array}$ \\
\hline $\begin{array}{l}\text { WWT Manager: "unclear } \\
\text { allocation of cost in WT } \\
\begin{array}{l}\text { CCs, no transparency what } \\
\text { are the significant cost drivers } \\
\text { \& too significant increased } \\
\text { cost in 2015" }\end{array}\end{array}$ & $\begin{array}{l}\text { WWT correct } \\
\text { cost } \\
\text { allocation \& } \\
\text { optimization }\end{array}$ & $\begin{array}{l}\text { Clear, correct } \\
\text { llocation of all } \\
\text { WWT process } \\
\text { related cost \& must } \\
\text { not be }>4.7 \text { Bio } \\
\text { IDR per year. }\end{array}$ \\
\hline
\end{tabular}

\section{Measure (Pengukuran)}

Fase Measure bertujuan untuk mengetahui seberapa besar masalah yang terjadi. Data dugaan sementara yang di dapat sebelumnya di validasi dalam fase ini. Alat bantu statistik penting digunakan karena dalam fase ini banyak berhubungan dengan data. alat bantu six sigma yang di gunakan adalah Tool II, Operational Definition, Measurenment System Analysis, Data Collection Plan, Process Performance. Penting untuk menggunakan semua alat bantu di atas supaya apa yang sudah di ukur tervalidasi dengan benar sebelum ke Analyze phase. 


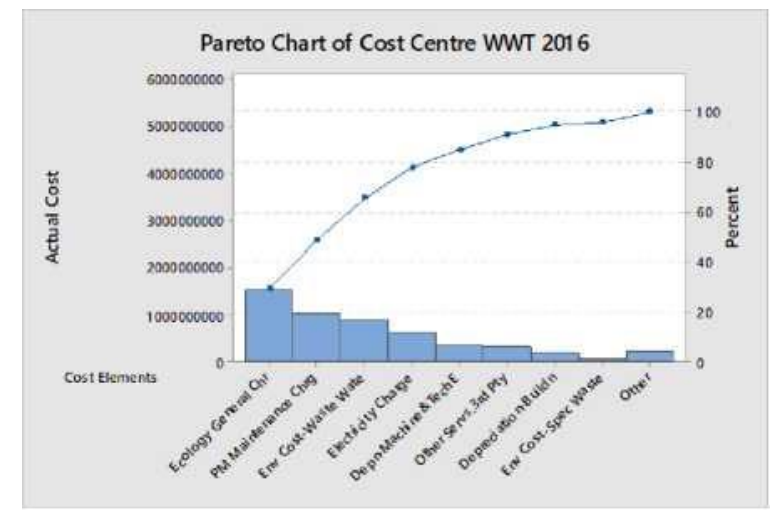

Gambar 1 Diagram Pareto

Dari pareto chart yang di atas teridentifikasi $80 \%$ biaya tertinggi yang di gunakan dalam operasional Waste Water Treatment di tahun 2015, dari total 30 cost element terdapat 4 cost terbesar yang akan di jadikan fokus dalam fase analisa nanti, tidak perlu 30 cost element dianalisa karena akan membutuhkan waktu yang lama dan tidak efisien. 4 cost element yang teridentifikasi besar penggunaannya adalah

a) Ecology general charge (gaji karyawan \& tunjangan)

b) PM Maintenance charge (biaya perbaikan mesin)

c) Env. cost waste water (pembelian kimia untuk proses)

d) Electricity charge (biaya listrik)

Analyze (Analisa)

Setelah apa masalahnya dan seberapa maslahnya sudah di temukan di fase sebelumnya maka di fase ini bertujuan untuk menemukan potensi akar masalah dan verifikasi akar masalah sehingga dapat di tentukan benar - benar akar masalah yang menyebabkan terjadinya suatu masalah. Alat six sigma yang digunakan adalah Fishbone (diagram sebab akibat). Fishbone atau ISHIKAWA di gunakan sebagai langkah awal untuk mengumpukan potensi akar masalah dengan brainstorming \& brainwriting melibatkan semua team member yang bekerja sehari - hari. Akar masalah akan di gali sedalam mungkin untuk benar - benar menemukan suatu akar permasalahan yang jelas dengan menggunakan metode $5 \mathrm{x}$ why sehingga dapat di visualkan antara masalah dan akar penyebabnya. Spesifik masalah sudah di tetapkan untuk mengisi di kepala ikan " kenapa biaya operasional Waste Water Treatment di 2015 mencapai 5,3 milyar ?" dari spesifik masalahnya akan di gali beberapa akar penyebanya sehingga saling berkaitan. Akar penyebab masalah datang dari team member yang bekerja sehari - hari, tugas project leader hanya memimpin Fishbone workshop dan memverifikasi apakah akar masalah yang di ungkapkan sesuai dengan masalah apa tidak. Dalam menentukan akar masalah juga dapat di kategorikan menjadi 3 bagian yaitu:

Tabel 2 Potensi Akar Masalah

\begin{tabular}{|l|l|l|l|l|}
\hline No & \multicolumn{1}{|c|}{ Methode } & \multicolumn{1}{|c|}{ Man } & \multicolumn{1}{|c|}{ Material } & $\begin{array}{l}\text { Mother } \\
\text { NIntan }\end{array}$ \\
\hline 1 & $\begin{array}{l}\text { Tidak ada work instruction } \\
\text { untuk dosing kimia (Variable } \\
\text { XI) }\end{array}$ & $\begin{array}{l}\text { Autonomous } \\
\text { maintenance } \\
\text { belum di } \\
\text { kenalkan di } \\
\text { operator Waste }\end{array}$ & $\begin{array}{l}\text { Masih banyak } \\
\text { me lakukan } \\
\text { pengolahan air } \\
\text { limbah di } \\
\text { continuous }\end{array}$ & $\begin{array}{l}\text { Collection pit } \\
\text { air limbah } \\
\text { tidak tertutup } \\
\text { sehingga air } \\
\text { hujan masuk }\end{array}$ \\
\hline 2 & $\begin{array}{l}\text { Trickling filter masih di } \\
\text { operasikan meskipun sudah. } \\
\text { ada aeration, tank (Noise 1) }\end{array}$ & $\begin{array}{l}\text { Biaya } \\
\text { maintenance } \\
\text { tidak pemah di } \\
\text { review secara }\end{array}$ & $\begin{array}{l}\text { Solid content } \\
\text { filter press } \\
\text { cake rendah } \\
\text { (Noise 2) }\end{array}$ & \\
\hline
\end{tabular}




\begin{tabular}{|l|l|l|l|}
\hline 3 & $\begin{array}{l}\text { Pengecekan sample terlalu } \\
\text { banyak (Variable } \\
\text { X5) }\end{array}$ & & \\
\hline 4 & $\begin{array}{l}\text { Terlalu cepat pergarttian kain } \\
\text { filter press (Variable X6) }\end{array}$ & & \\
\hline 5 & $\begin{array}{l}\text { Penyesuaian pH yang kurang } \\
\text { tepat sehingga boros } \\
\text { penggunaan bahan kimia } \\
\text { untuk proses (Variable X7) }\end{array}$ & & \\
\hline 6 & $\begin{array}{l}\text { Testing berulang yang di } \\
\text { lakukan }\end{array}$ & & \\
\hline 7 & $\begin{array}{l}\text { Sistem shift tidak berubah } \\
\text { meskipun ada perubahan } \\
\text { pekeriaan (Noise 5) }\end{array}$ & & \\
\hline
\end{tabular}

$\mathrm{C}=$ Constant $($ sesuatu yang tidak dapat di rubah)

a. $\quad \mathrm{N}=$ Noise (dapat dirubah tetapi susah)

b. $\mathrm{X}=$ Variable (sesuatu yang dapat di rubah dengan cepat)

Hal ini penting untuk di lakukan supaya lebih terkonsep dan terfokus untuk menemukan solusi dari masalah yang variable. Prioritas akar masalah yang akan di tentukan solusi adalah akar masalah yang variable dengan mempertimbangkan effort dan benefit. Akar masalah yang di rumuskan juga mengacu terhadap 5M yaitu material, method, machine, money, mother nature.

Improve (Perbaikan)

Fase Improve atau tahap perbaikan berkaitan dengan penentuan dan implementasi solusi-solusi berdasarkan hasil analisis yang telah dilakukan sebelumnya pada fase Analyze Pada penelitian ini, aktivitas yang dilakukan pada fase improve adalah penentuan solusi-solusi atau tindakan-tindakan untuk mengatasi permasalahan tingginya cost di departemen Waste Water Treatment. Pada tahap inilah penulis memberikan masukan-masukan mengenai usaha perbaikan proses berdasarkan hasil analisis yang telah didapatkan dari tahap sebelumnya. Pada proyek penerapan analisa DMAIC setelah diketahui tindakan apa yang bisa dilakukan maka tindakan itu akan diimplementasikan sebagai usaha untuk memecahkan masalah yang terjadi.

Tabel 3 Solusi

\begin{tabular}{|c|l|c|}
\hline No & \multicolumn{1}{|c|}{ Solutions } & Which Root Cause is Impacted \\
\hline 1 & $\begin{array}{l}\text { Membuat WI untuk dosing bakan kimia } \\
\text { ke proses limbah. }\end{array}$ & $\begin{array}{c}\text { Tidak ada work instruction untuk dosing } \\
\text { kimia. }\end{array}$ \\
\hline 2 & $\begin{array}{l}\text { Shut down trickling filter dan hanya } \\
\text { menggunakan tanki aerasi untuk proses } \\
\text { bioloei. }\end{array}$ & $\begin{array}{l}\text { Trickling filter masih di operasikan } \\
\text { meskipun sudah ada aeration tank. }\end{array}$ \\
\hline 3 & $\begin{array}{l}\text { Biaya maintenance di review setiap bulan } \\
\text { dan di diskusikan saat }\end{array}$ & $\begin{array}{l}\text { Biaya maintenance tidak pemah di review } \\
\text { seeara rutin. }\end{array}$ \\
\hline 4 & $\begin{array}{l}\text { Training Autonomous Maintenance ke } \\
\text { semua operator Waste Water Treatment. }\end{array}$ & $\begin{array}{c}\text { Autonomous maintenance belum di } \\
\text { impelemntasikan di WWT departemen. }\end{array}$ \\
\hline
\end{tabular}




\begin{tabular}{|c|l|l|}
\hline 5 & $\begin{array}{l}\text { Melakukan pengolahan limbah cair hanya } \\
\text { di manual treatment. }\end{array}$ & $\begin{array}{l}\text { Masih banyak melakukan pengolahan air } \\
\text { limbah di continuous process. }\end{array}$ \\
\hline 6 & Merubah sistem shift dari 6-2 ke 5 - 2. & $\begin{array}{l}\text { Sistem shift tidak berubah meskipun ada } \\
\text { perubahan pekerjaan. }\end{array}$ \\
\hline
\end{tabular}

Dari solusi - solusi yang sudah di sepakati di atas akan di implementasikan bertahap tujuannya untuk memfokuskan dalam penerapan solusi dan controlnya, sebelum masuk ke dalam fase kontrol solusi yang di terapkan harus benar - benar sudah di evalusi dengan baik. Di butuhkan waktu kurang lebih 3 bulan dalam evaluasinya untuk mempersiapkan dengan matang apakah ada yang perlu di buat, pembelian alat - alat baru, investigasi kemungkinan masalah lain akan muncul dan tentunya harus di diskusikan dengan safety jika ada yang berkaitan dengan isu safety dengan membuat MOC (management of change). Nantinya sebelum masuk ke dalam fase Control project leader harus memastikan semua solusi yang telah di sepakati diatas akan berejalan dengan baik. Ini penting di lakukan supaya masalah lain tidak muncul.

Control (Pengendalian)

Fase Control atau tahap pengendalian adalah tahap yang bertujuan untuk terus mengevaluasi dan memonitor hasil-hasil dari tahap sebelumnya atau hasil implementasi yang telah dilakukan pada fase improve. Tahap ini juga bertujuan untuk memastikan bahwa kondisi yang sudah diperbaiki dapat berlangsung terus menerus atau berkesinambungan, dan tidak berjalan dalam waktu yang singkat saja. Setelah solusi-solusi

diimplementasikan pada fase improve untuk meningkatkan performa proses, maka fase control menjaga agar performa tersebut tidak menurun kembali. Pada fase ini penulis berusaha memberikan masukan kepada perusahaan tentang cara pengendalian dan pengawasan (monitoring) proses. Aktivitas yang dilakukan pada tahap ini adalah melakukan pengecekan terhadap standar pengukuran performa yang digunakan, dan melakukan pengecekan terhadap dokumen-dokumen atau laporan- laporan yang diperlukan.

Alat bantu statistik di perlukan dalam fase ini seperti run chart untuk mengevaluasi hasil yang sudah di lakukan dalam perbaikan project six sigma. Semua yang sudah di perbaiki dalam fase sebelumnya di tuangkan dalam SOP dan di monitor selama 1 tahun untuk memastikan biaya Waste Water Treatment tidak bermasalah lagi. Berikut adalah hasil control dalam run chart selama 3 bulan pertama implementasi project yang sudah di dokumentasikan.

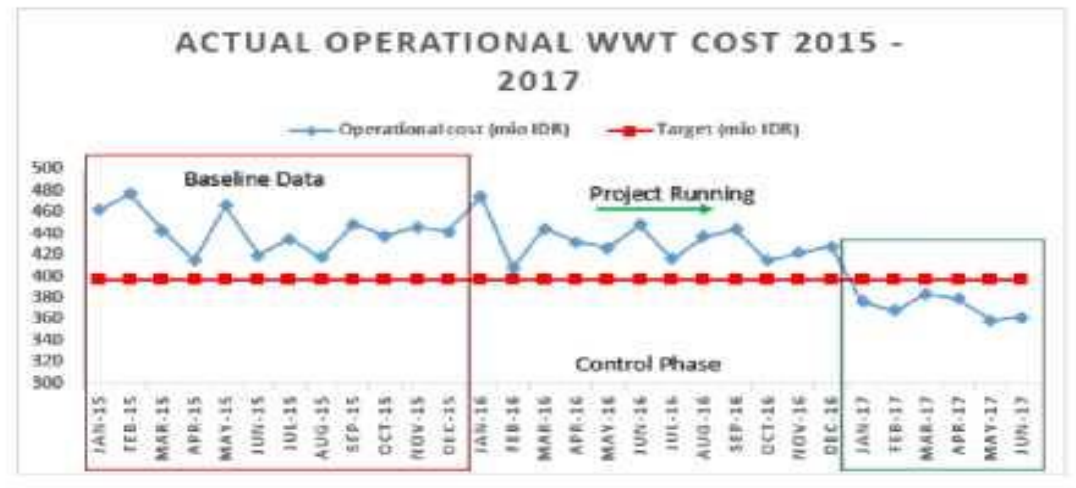

Gambar 2 Run Chart Improvement

Dari chart di tersebut menjelaskan hasil improvement yang sudah di lakukan dan di dokumentasikan didalam chart. Rata - rata biaya yang di habiskan di departemen Waste Water Treatment di tahun 2015 adalah 441 juta/bulan, target pengurangan $10 \%$ per bulan (44 juta/bulan) menjadi max 397 juta/ bulan. Tetapi hasil pencapaian lebih bagus yaitu kurang dari max target. Sampai 6 bulan Control phase hard benefit yang sudah di klaim adalah 326 juta. Hasil tersebut akan terus di pantau sampai 12 bulan ke depan/ akhir tahun 2017. Jika masih konsisten hasilnya maka project six sigma yang dilakukan telah berhasil, tetapi jika terjadi masalah project leader harus melakukan evaluasi dan melalukan reaction plan terhadap masalah yang terjadi. Beberapa

JIM, Vol. 3, No. 2, Juli 2018, pp.59-66 
action plan yang sudah ditetapkan di dalan Control phase yaitu:

1. Jika biaya Maintenance tinggi, maka cek notifkasi yang sudah di buat apakah sesuai dengan budget atau melebihi. Jika sesuai maka cek upload dokumen dari pihak Finance di dalam cost centre. Jika melebihi maka dilihat ada modifikasi atau breakdown mesin atau pompa.

2. Jika biaya Listrik tinggi, maka cek konsumsi listrik actual di SCADA bagian Utility. Jika sesuai maka cek upload dokumen yang di posting oleh Finance. Jika melebihi maka cek ada aktivitas apa yang terjadi di internal Waste Water Treatment.

3. Jika biaya pembelian kimia tinggi maka cek konsumsi kimia yang digunakan untuk proses di Waste Water Treatment. Jika sesuai maka cek dokumen yang di posting Finance. Jika melebihi cek debit air limbah yang masuk ke Waste Water Treatment dan parameter parameter nya.

\section{KESIMPULAN}

Berdasarkan penelitian yang telah dilakukan di PT. Clariant Indonesia mengenai penerapan six sigma untuk mengurangi pemborosan biaya operasional dapat disimpulkan beberapa hal sebagai berikut :

1. Telah di ketahui dan definisikan dengan jelas tentang bagimana cara menerapkan methodology six sigma secara terstruktur untuk mengurangi pemborosan biaya operasional Waste Water Treatment sehingga dapat dicapai hasil yang di inginkan. Tahapan DMAIC dilakukan secara terstruktur dengan timeline yang jelas, serta di setiap fase digunakan alat bantu six sigma untuk memudahkan dalam pengumpulan data, analisa data ataupun untuk menentukan akar masalah dan solusi yang telah di dapat dari workshop meeting.

a. Fase Define adalah awal dimulai penerapan six sigma dimulai dengan menjelaskan latar belakang project, merumuskan masalah dan tujuan, menetapkan team project dan time line yang jelas yang terangkum di dalam project charter kemudian membentuk SIPOC yang bertujuan untuk mengetahui gambaran awal proses yang akan di analisa dan customer needs yang ingin di capai.

b. Fase Measure adalah tahapan pengumpulan data yang bertujuan untuk mengathui seberapa besar masalah yang terjadi. Dalam fase ini semua data yang terkumpul dianalisa menggunakan alat bantu six sigma Diagram Pareto untuk mengetahui biaya apa saja yang berkontribusi paling besar di dalam cost centre Waste Water Treatment.

c. Fase ketiga adalah Analyze, dalam fase ini terkumpul beberapa akar masalah yang di dapat dari Fishbone workshop dengan team dan champion project. Setelah potensi akar masalah terkumpul selanjutnya di cluster untuk memprioritaskan akar masalah apa saja yang akan di follow up pertama sebagai prioritas.

d. Fase keempat adalah Improve, fase ini menetapkan solusi - solusi untuk mengatasi akar masalah yang telah terkumpul dan di sepakati semua team.

e. Fase terakhir adalah Control, fase ini adalah tahapan dimana semua perbaikan yang telah dilakukan di kontrol semua solusi yang telah di tetapkan dan benefit - benefit yang

f. telah di dapatkan. Jika ada ketidak sesuaian maka project leader akan melakukan evaluasi dengan menyusun action list jika performa perbaikan menurun atau kembali lagi masalah yang telah di perbaiki.

2. Telah di ketahui dengan jelas semua akar masalah yang menyebabkan pemborosan biaya operasional Waste Water Treatment dari Fishbone workshop dengan semua team yang terlibat. Akar masalah yang telah terkumpul kemudian di bagi menjadi 3 kriteria yaitu Constant, Noise, Variable. Kemudian di kelompokan menjadi 5 bagianMan, Methode, Machine, Material, Maother Nature.

3. Telah di tetapkan solusi - solusi untuk menindak lanjuti dari akar masalah yang terkumpul dan di sepakati semua team. Solusi yang di terapkan di harapkan mampu untuk memecahkan masalah yang terjadi tentang pemborosan biaya operasional Waste Water Treatment sehingga 
ke depan masalah tersebut tidak akan terjadi lagi di kemudian hari.

\section{SARAN} berikut:

Berdasarkan hasil penelitian yang diperoleh dapat disarankan beberapa hal sebagai

1. Team member dapat dilakukan training yellow belt sebagai dasar dan pemahaman penuh terhadap continuous improvement.

2. Meningkatkan kesadaran dan keterlibatan operator Waste Water Treatment dalam pengendalian biaya operasional.

3. Mengintegrasikan program continuous improvement dengan program rewarding karyawan supaya lebih merasa memiliki dan termotivasi untuk melakukan sesuatu kearah yang lebih baik Memiliki system dan melibatkan semua operator untuk menanggulangi biaya maintenance yang berlebih, lebih banyak melakukan training internal melibatkan perwakilan dari tim Engineering.

4. Diperlukan penelitian lebih lanjut untuk memverifikasi beberapa akar masalah yang belum di temukan solusinya dengn alat bantu six sigma yang lain.

\section{DAFTAR PUSTAKA}

Alfita, Riza. 2011, Perancangan Sistem Pendukung Keputusan Penentuan Prioritas Produk Unggulan Daerah Menggunakan Metode Weighted Product (WP). Universitas Trunojoyo, Madura.

Arifin, Miftachul, 2012, Aplikasi Metode Lean Six Sigma Untuk Usulan Improvisasi Lini Produksi Dengan Mempertimbangkan Faktor

Lingkungan. Studi Kasus: Departemen GLS ～(General

Lighting Services) PT. Philips Lighting Surabaya, Jurnal Ilmiah Teknik Industri

Brue, G. 2002, Six Sigma for Managers, Canary, Jakarta

Cindy, Marika. 2014, Penerapan six sigma dan activity based costing pada perusahaan garmen PT. $\mathrm{X}$.

Emilasari, D. 2003, Sudi Perbaikan Kualitas terhadap Defect dengan Menggunakan Metode DMAIC di PT X, Tugas Akhir Jurusan Teknik Industri ITS.

Gaspers, Vincent. 2012, Pedoman implementsi program Six Sigma, Jakarta, PT Gramedia Pustaka Utama

Gomez, Nunez, 2009. Implementation of Six Sigma in a Manufacturing Process: A Case Study

Kunal, Ganguli, 2012, Improvement process for rolling mill through the DMAIC six sigma approach.

Lunau, Stephan. 2013, Six Sigma + Lean Toolset. Penerbit UMS, Springer- Verlag Berlin Heidelberg.

Mostafa, Lutfi. 2013, Productivity improvement by using six sigma

Mostafa, Zaenudin. 2014, Implementation of six sigma in service industry.

Riesky, Syahidri, 2009, Pendekatan six sigma sebagai upaya untuk meminimasi waste pada proses pengemasan industri farmasi.

Sarkar, D. 2008, Lean for Service Organizations and Offices : A Holistic Approach for Achieving Operational Excellence and Improvements. ASQ Quality Press, Milwaukee.

Wignjosoebroto, 1995, Ergonomi Studi Gerak dan Waktu Teknik Analisis untuk Peningkatan Produktivitas Kerja. Surabaya: PT. Guna Widya.

Yorie, Marg Bonifaius, 2014 Pendekatan six sigma dengan metode weighted product untuk mengurangi waste pada proses produksi.

JIM, Vol. 3, No. 2, Juli 2018, pp.59-66 